\title{
Mesosaurid Swim Traces
}

\author{
Rafael C. da Silva ${ }^{1 *}$ and Fernando A. Sedor \\ ${ }^{1}$ Departamento de Geologia, CPRM-Serviço Geológico do Brasil, Rio de Janeiro, Brazil, ${ }^{2}$ Museu de Ciências Naturais, Setor \\ de Ciências Biológicas, Universidade Federal do Paraná, Curitiba, Brazil
}

Despite subaqueous fossils tracks of tetrapods being quite common in the fossil record, few studies discuss their classification and morphofunctional interpretation. Even with their simple morphology, some important information about the trackmakers can be retrieved from these tracks. Subaqueous traces were found in Brazil in the Irati Formation (Cisuralian, Permian), Paraná Basin, and described as Mesosaurichnium natans, related to Mesosauridae. The traces were produced in a shallow marine environment, whose substrate contained crustacean shells forming a thin layer. The mesosaurids produced the traces by swimming close to the bottom. The propulsion was provided by undulatory moves of the long tail, mainly for faster swimming. The feet could act as accessory and slower propellants, but provided more maneuverability.

\section{OPEN ACCESS}

Edited by:

Michel Laurin,

Centre de Recherche Sur la

Paléobiodiversité et les

Paléoenvironnements, France

Reviewed by:

Tracy Joseph Thomson, University of California, Davis, USA

Juan Carlos Cisneros,

Universidade Federal do Piauí, Brazil Alina Chrzastek

Wroclaw University Poland, Poland

${ }^{*}$ Correspondence:

Rafael C. da Silva paleoicno@yahoo.com.br; rafael.costa@cprm.gov.br

Specialty section:

This article was submitted to Paleontology,

a section of the journal

Frontiers in Ecology and Evolution

Received: 29 August 2016

Accepted: 17 March 2017

Published: 04 April 2017

Citation:

da Silva RC and Sedor FA (2017)

Mesosaurid Swim Traces.

Front. Ecol. Evol. 5:22.

doi: $10.3389 /$ fevo.2017.00022
Keywords: mesosauridae, traces, swimming, subaqueous, permian, Mesosaurichnium

\section{INTRODUCTION}

Mesosaurids are traditionally recognized as fully aquatic animals. In fact, they were the first amniotes to develop adaptations to aquatic habits, such as a long body and laterally flattened tail, an elongate rostrum, nostrils close to the orbits, thick pachyosteosclerotic ribs (which could increase the ability of submersion) and interdigital webbing forming paddle-like hands and feet (e.g., Cope, 1886; McGregor, 1908; Rösler and Tatizana, 1983; Canoville and Laurin, 2010). Also, their hind limbs are longer and sturdier, suggesting a peculiar form of underwater locomotion based on movement of the feet rather than the hands.

The rocks where mesosaurs were found consist mostly of limestones and shales of marine origin, corroborating the aquatic interpretation for these animals (e.g., Oelofsen and Araújo, 1983, 1987; Lavina et al., 1991). Other interpretations also include hypersaline lagoons (e.g., Piñeiro et al., 2012). Many taphonomic and sedimentological studies have shown that their skeletons show little or no evidence of transport and are close to or in the place where they lived, and there are virtually no terrestrial environments of the same age preserved in these sedimentary rocks (e.g., Oelofsen and Araújo, 1983, 1987; Lavina et al., 1991; Soares, 2003).

Despite the abundance of mesosaurid fossils, their traces are quite rare and are only known from three sites in Brazil (Silva et al., 2009). The morphology of these traces reflects direct evidence of the locomotion of these animals, helping to better understand their life habits. Here, the terminology for subaqueous traces follows McAllister (1989) and Thomson and Lovelace (2014).

\section{GEOLOGICAL CONTEXT}

All the known material consists of 25 rock samples from the Irati Formation, Paraná Basin, Brazil, collected between 1996 and 2003 (Figure 1). The specimens belong to the paleontologic collection of Museu de Ciências Naturais, Universidade Federal do Paraná, located in Curitiba, Paraná, Brazil. Digital 3D models of some samples were built using Autodesk 123D Catch open source software (Figure 2). 


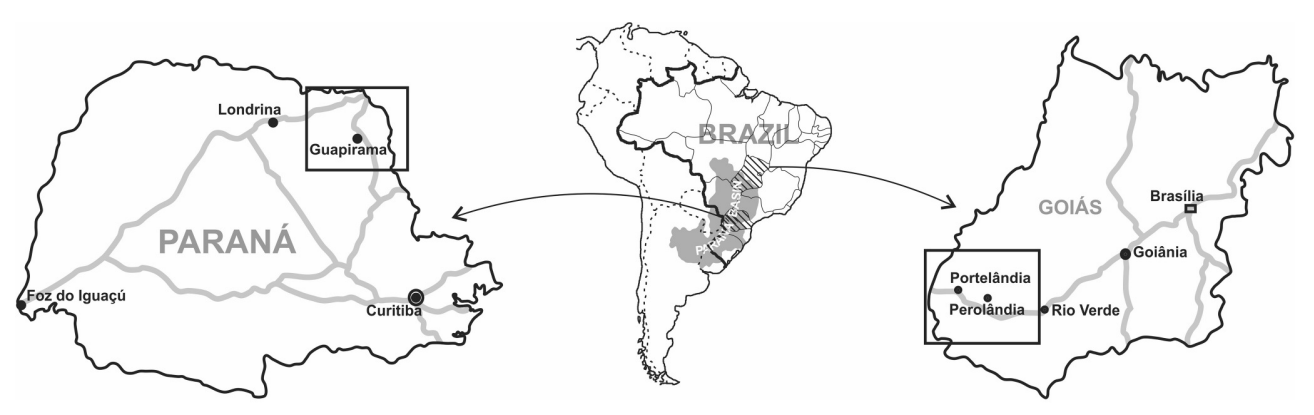

FIGURE 1 | Location of mesosaurid traces ocurrences at Paraná and Goiás States, Brazil.

Samples MCN.P.293a-c, MCN.P.760-767, MCN.P.774, and MCN.P.851-854 are from Codapar limestone quarry in Guapirama, Paraná $\left(23^{\circ} 27^{\prime} 09.96^{\prime \prime} \mathrm{S}\right.$; $50^{\circ} 02^{\prime} 10.92^{\prime \prime} \mathrm{W}$, Figure 1). The crustacean shells from these beds show size selection and orientation by bimodal flow (Silva et al., 2009). The samples MCN.P.262 and MCN.P.266 come from a limestone quarry in Portel $\beta$ ndia, Goiás ( $17^{\circ} 20^{\prime} 18.96^{\prime \prime} \mathrm{S}$; $52^{\circ} 37^{\prime} 23.88^{\prime \prime} \mathrm{W}$, Figure 1). Samples MCN.P.426-428 come from another limestone quarry in Perolßndia, Goiás $\left(17^{\circ} 29^{\prime} 00.0^{\prime \prime}\right.$ S; $52^{\circ} 03^{\prime} 11.60^{\prime \prime} \mathrm{W}$, Figure 1). Possible occurrences of mesosaurid traces elsewhere were investigated but so far remain inconclusive, lacking better evidence. Most of the studied samples shown traces in convex hyporelief, which may reflect a bias once they are easily recognized in the field.

The Paraná Basin is a very extensive intracratonic basin with Paleozoic and Mesozoic rocks (e.g., Schneider et al., 1974; Milani et al., 1994, 2007), covering parts of Argentina, Paraguay, Uruguay and Brazil. The Passa Dois Group is a Permian geological unit that comprises several formations, among which the Irati Formation is the oldest (Mendes, 1967; Milani et al., 1994, 2007). The Irati Formation contains mudstones, dark shales, limestones and sandstones, with horizontal lamination, cross lamination, oolites, ripple marks and intraformational conglomerates (Schneider et al., 1974). The Irati Formation was deposited in a wide epicontinental sea in southern Gondwana (Lavina, 1991; Milani et al., 1994, 2007). The Whitehill Formation in Southern Africa, the Gai-As Formation in Namibia, the Uruguayan Mangrullo Formation and part of the Argentine Chacabuco Formation are correlated with the Irati Formation by fossils, lithology or both (Lavina, 1991; Milani et al., 1994, 2007; Rubidge, 2005). Despite controversies involving early datings, the Irati Formation was formally dated as Artinskian (Premaor et al., 2006; Santos et al., 2006).

There are many environmental interpretations for the Irati Formation, but most agree about the facies that preserve the traces, which were possibly deposited between supra and subtidal zones as carbonate banks (Figueiredo Filho, 1972; Lavina, 1991). Nevertheless, the Guapirama site shows crustacean beds associated with hummocky cross stratification, suggesting this deposit formed between fair weather and storm wave base (e.g., Santos Neto, 1993; Hachiro and Coimbra, 1991; Walker and Plint, 1992; Silva et al., 2009).

\section{TERRESTRIAL AND AQUATIC FOSSIL TRACKS AND TRACES}

Fossil tracks are singular structures and often need to be analyzed under sedimentological as well as morphological criteria, because they are formed in sedimentary substrates with varied plasticity and require very specific conditions for their preservation. In traditional view, tracks are usually produced as impressions of autopodia on the substrate surface, which after drying becomes strong enough to support a new episode of sedimentation (e.g., Lockley, 1991; Milàn and Bromley, 2006). Thus, tracks are found between allochronous sedimentary layers and are generally associated with mud cracks, sole marks or erosive structures.

Sometimes the trackmaker may step on a fresh plastic substrate, crossing through it and reaching a harder sediment below (e.g., Brand and Kramer, 1996; Loope, 2006; Milàn and Bromley, 2006; Silva et al., 2012a,b). When removing the foot, the sediment around it collapses and immediately buries and preserves the track. In this case, the layer with the imprint and the others which covers it are synchronous. This process can enhance the preservation potential of tracks as it eliminates the requirement of aerial exposure after their generation to dry and preserve them. This kind of preservation can be understood as a variation of classic undertracks and ghostprints, and is similar to what was called "cut undertracks" by Goldring and Seilacher (1971). In both cases, the formation of tracks involves rupture of the upper layers and folding of the lower layers, creating typical deformational structures below and around the imprints.

Also important is the "Goldilocks" effect (Falkingham et al., 2011, 2014), in allusion to the story of "Goldilocks and the Three Bears," according to which only a narrow range of loads can produce tracks, since loading conditions for a homogeneous substrate must be "just right" in order for the animal to be able to traverse the area but still form tracks. Such assemblages most likely represent a strongly biased preservation, or an "instantaneous" event (Falkingham et al., 2011, 2014). Although the concept has been developed for load tracks, the general idea could be applied to subaqueous traces, which would only be preserved in a specific set of sedimentary conditions, environmental energy or depth of autopodia penetration in the sediment.

A subaqueous trace is not so different from terrestrial tracks and can be produced basically during half-swimming in shallow 
A

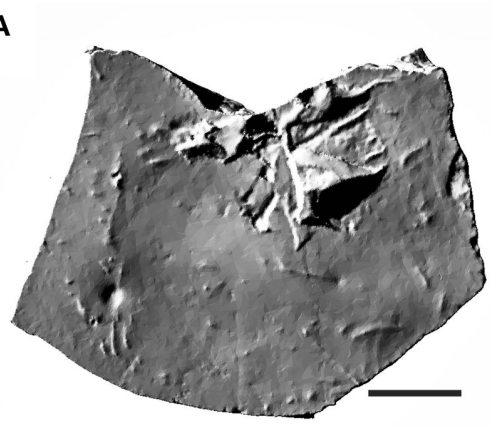

B

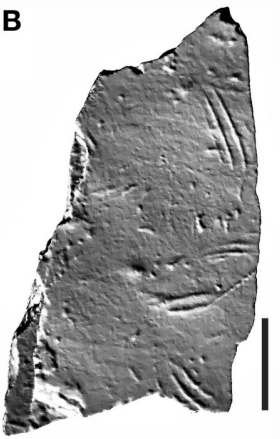

C

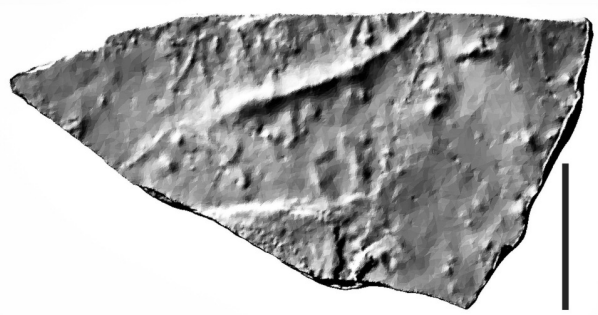

D

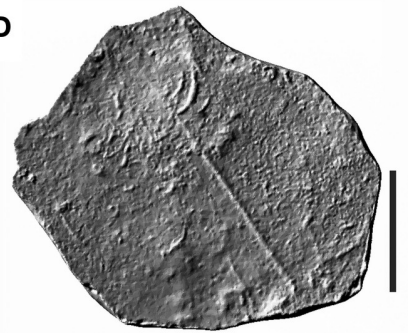

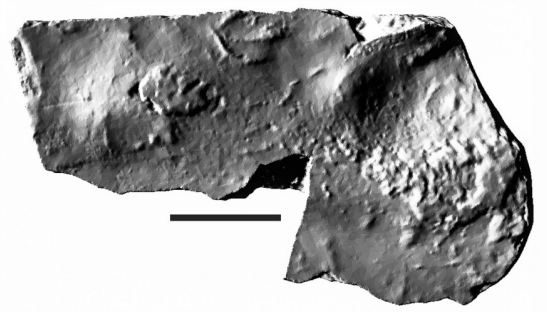
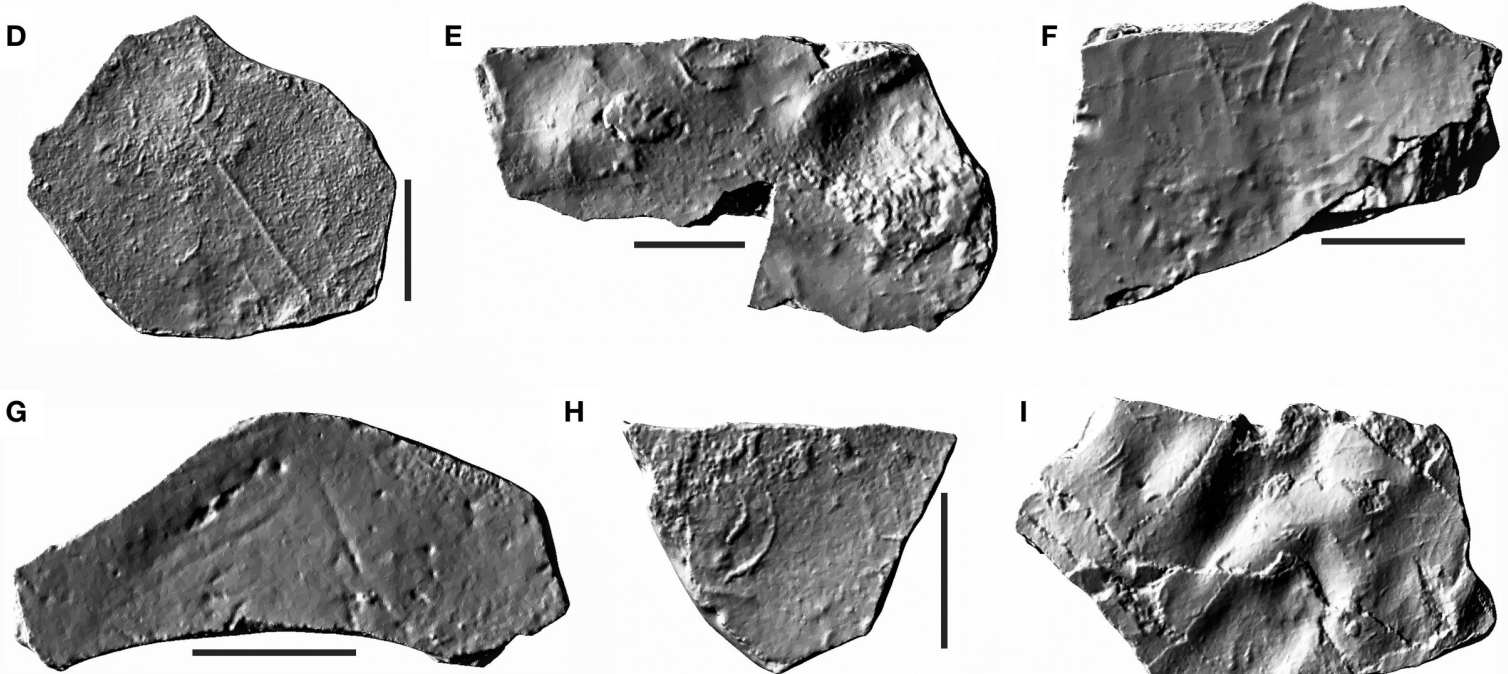

H
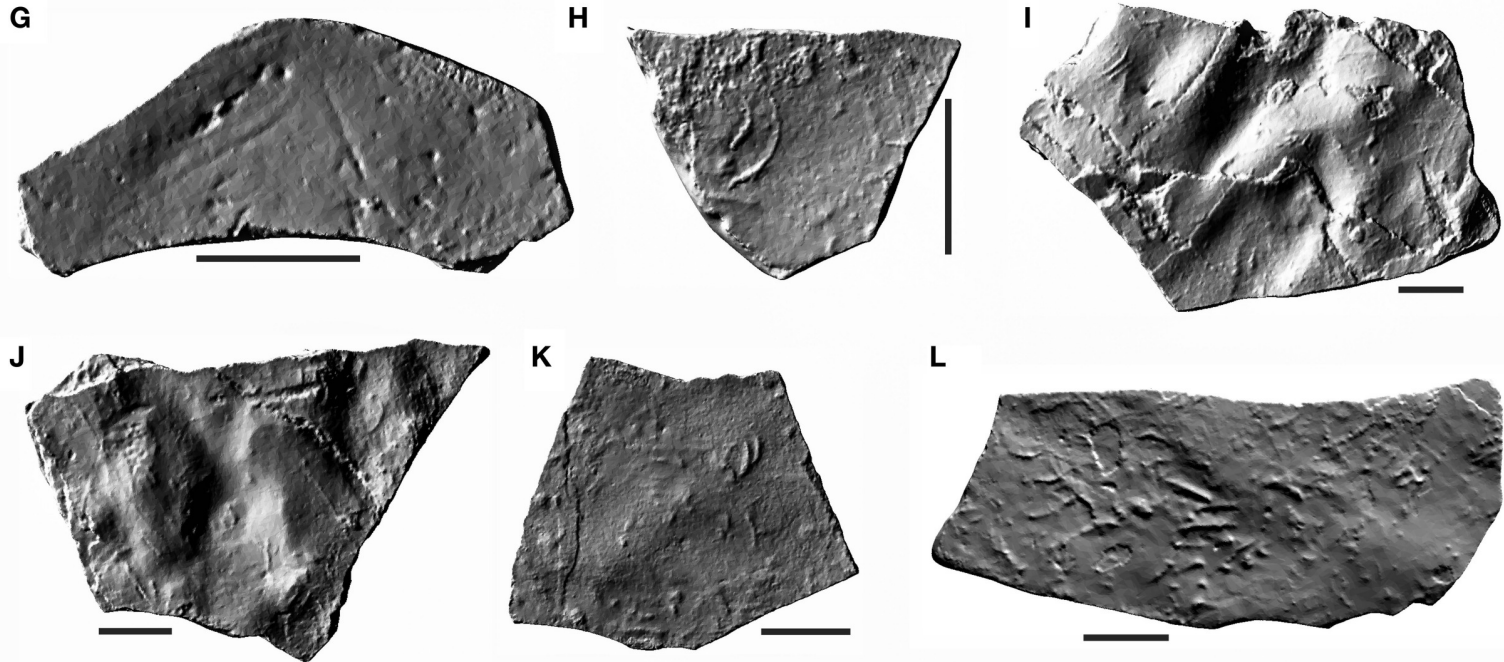

$\mathbf{L}$
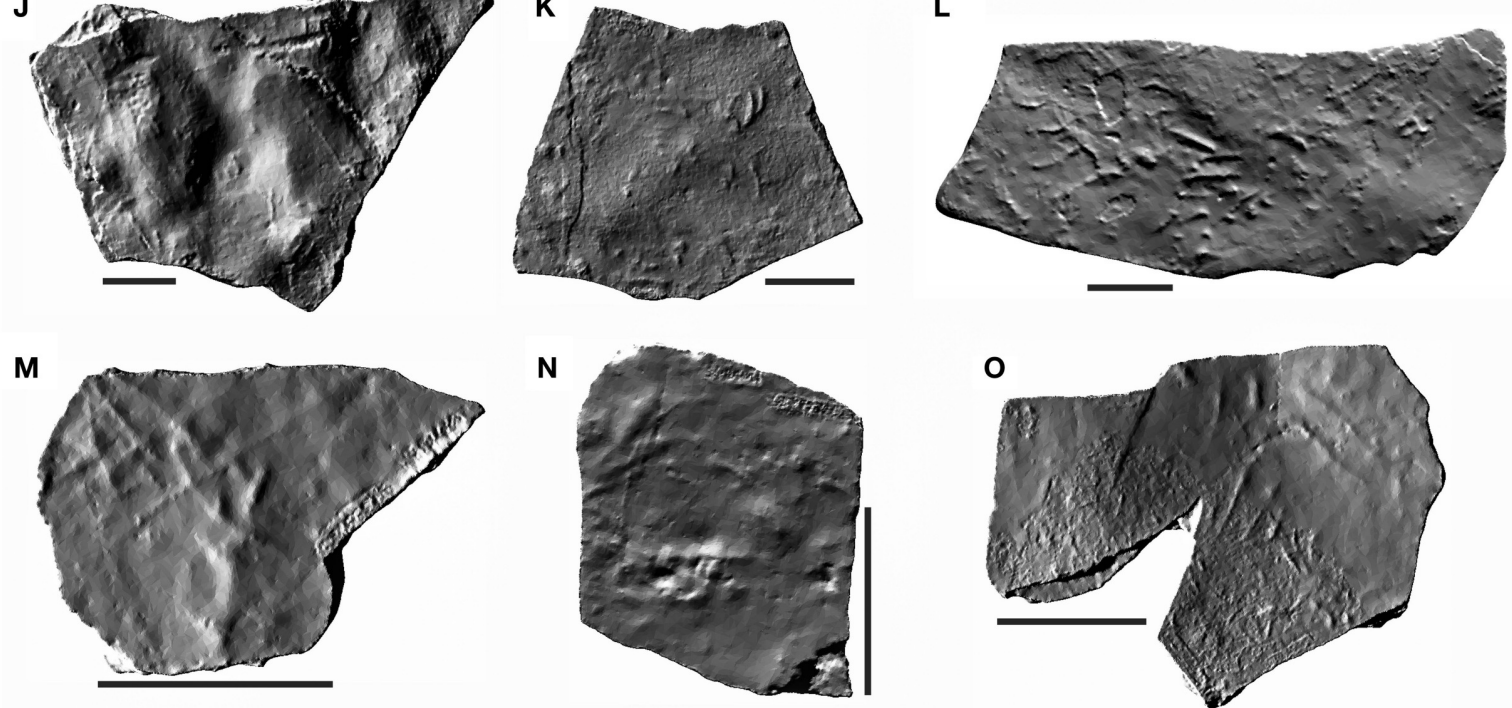

FIGURE 2 | Digital 3D models of samples from the Irati Formation (Cisuralian, Permian, Paraná Basin) with Mesosaurichnium natans. (A) MCN.P.293a. (B) MCN.P.293b. (C) MCN.P.760. (D) MCN.P.762. (E) MCN.P.763. (F) MCN.P.764. (G) MCN.P.765. (H) MCN.P.766. (I) MCN.P.852b. (J) MCN.P.852C. (K) MCN.P.262. (L) MCN.P.266. (M) MCN.P.426. (N) MCN.P.427. (O) MCN.P.428. Scale bar $=5 \mathrm{~cm}$. 
water, with digits touching the bottom while the body and tail float, or during swimming close to the bottom, with the whole body submerged. Normally, an animal swimming with the body fully supported by water does not have to push the autopodia against the bottom to move and thus will not leave tracks in the substrate. However, variations in water level or irregularities in the topography of substrate may cause contact with the bottom (e.g., Romano and Whyte, 2010; Thomson and Lovelace, 2014). The morphology of the traces is controlled both by the behavior of the animal and by the anatomical features, which can make the identification of the tracemaker difficult (Thomson and Lovelace, 2014). Mixtures of terrestrial and subaqueous traces, or traction and swimming traces, in different degrees can occur when there are variations in the water column along the deposition or in the size of tracemakers (Foster and Lockley, 1997; Diedrich, 2000, 2002; Silva et al., 2008; Campos and Silva, 2010). In this context, an effect similar to "Goldilocks" can occur not by load but by the depth of penetration of fingertips into the sediment. Several features can be used to recognize subaqueous traces and identify the maker, mainly related to elongated and curved marks of variable lengths and chaotic configurations, number of drag marks, width and pattern of traces in a traceway and more rare features such as body or tail drag marks (McAllister, 1989; McAllister and Kirby, 1998; Thomson and Lovelace, 2014).

As pointed out by Thomson and Droser (2015), the preservation of swim traces may be related to low bioturbation activity evidenced by the rarity of invertebrate ichnofossils in the Irati Formation (Silva et al., 2003). The presence of bioturbation is a factor that diminishes the preservation potential of primary sedimentary structures and traces. The virtual absence of bioturbation is probably due to the high salinity in the depositional systems that originated the Irati Formation (e.g. Oelofsen and Araújo, 1983, 1987; Lavina et al., 1991; Silva et al., 2003; Piñeiro et al., 2012).

\section{THE MESOSAURIDAE TRACES}

Mesosaurichnium natans (Silva et al., 2009) Emmended diagnosis: traces composed by two to five parallel or slightly divergent elongated marks, without striations, which are regularly spaced and curved, with the internal side of the curve turned medially. The anterior extremity of each mark is acute while the posterior end is wider than the anterior and medially curved with a rounded end. When four or five marks are present in a trace, the central ones are longer and deeper than the others. The traces of the feet can form regularly spaced traceways with high pace angulation, about $150^{\circ}$, and length of stride of about $20 \mathrm{~cm}$. The average traces vary between 1 and $3 \mathrm{~cm}$.

The mesosaurid traces were previously described as a new ichnogenus and ichnospecies, Mesosaurichnium natans (Silva et al., 2009). The traces are elongated and narrow and central marks are commonly longer and deeper (Figures 3A-D). Usually, the arrangement of traces is chaotic and a few can be found forming segments of traceways. Some traces are also superimposed. Some variations also occur as one or two very long, straight or sinuous, parallel marks (Figures 3E,F), and long bifurcated sinuous marks, in addition to $\mathrm{V}, \mathrm{Z}$-shaped marks (Figures 3G-I). According to Silva et al. (2009), a statistical study of the traces reveals that mark length differs more than the width or interdigital distance. Some marks with a highly curved, comma-shaped extremity in their posterior end were interpreted as digit reflection at the end of the propelling stage (Thulborn and Wade, 1989). Thus, Mesosaurichnium is very recognizable and is clearly different from other subaqueous ichnogenera such as Undichna (Anderson, 1976), Hatcherichnus (Foster and Lockley, 1997), and Lunichnium (Walter, 1983), as pointed by Silva et al. (2009). Mesosaurichnium also differs from Characichnos (Whyte and Romano, 2001) by the much smaller and well defined range of size, regularity and number of the marks (up to five marks of digits in a trace), and by the presence of traceways. Characichnos also presents traces with longitudinal striations, interpreted as marks of scales, possibly representing a major portion of the digits (e.g., Lucas and Spielmann, 2009; Mikuláš, 2010). In fact, Characichnos is an ichnogenus based on somewhat vague characteristics and probably needs a revision.

Based both on sedimentary features and morphological interpretation, Mesosaurichnium natans was produced by the sole tetrapod found in the Irati Formation, the Mesosauridae (Silva et al., 2009). However, it is impossible to attribute the traces to one of the mesosaurid species due to their anatomical similarity (e.g., Araújo, 1976).

Although Sedor and Silva (2004) had interpreted the traces as half-swimming prints, they were subsequently interpreted as being produced as the animal plunged several meters deep based mainly on faciology (Lavina, 1991; Santos Neto, 1993; Silva et al., 2009). The absence of traction prints also supports this hypothesis, since their occurrence along with drag marks is typical of half-swimming traces (Silva et al., 2007, 2008, 2009; Romano and Whyte, 2010).

The study of the preservation of Mesosaurichnium natans by Silva et al. (2009) provides important clues about how the traces were produced. Usually, subaqueous traces are followed by kick-off scours produced by the stroke of the feet close to the bottom creating swirls, suspending and reworking the sediment behind the trace (e.g., McAllister and Kirby, 1998; Swanson and Carlson, 2002; Romano and Whyte, 2010). This feature, which indicates that the surface was exposed when the traces were produced, was not found in this material. Instead, in the limestone tempestite rocks where Mesosaurichnium occurs, the crustacean carapaces were redeposited during storm events together with reworked, fine grained carbonatic sediments, forming thin lenses between the shelly beds (Silva et al., 2009). When the tracemakers swam close to the bottom, their fingertips crossed the superficial shelly layer, reaching the lower layers of sediment already protected from erosion (Silva et al., 2009). This is similar to the aforementioned cut undertrack preservation, but is different from classic undertracks because no pressure of feet was applied on the bottom, deforming the lower layers. The nearly constant depth of the traces is probably related to how deep the fingers could penetrate the sediment (Silva et al., 2009). 

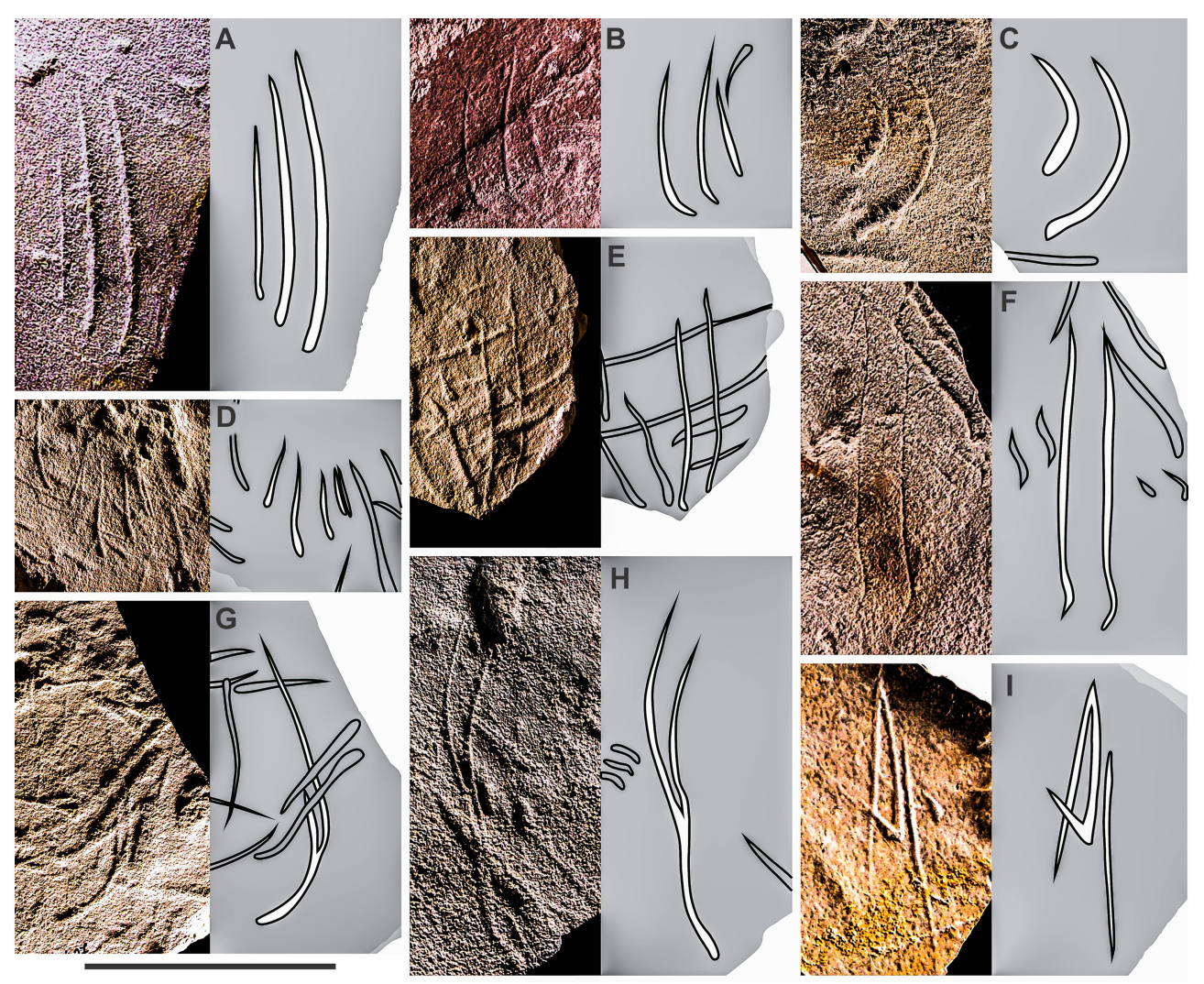

FIGURE 3 | Morphological features of Mesosaurichnium natans. (A-D)Curved traces with comma-shaped extremities. (E-F) Long and sinuous traces. (G-I)

$\mathrm{V}$ and Z-shaped traces. Scale bar $=5 \mathrm{~cm}$.

\section{FUNCTIONAL MORPHOLOGY OF MESOSAURIDS}

The distribution of mesosaurid traces in different samples is quite chaotic; since there is no traction on the substrate to propel the body, they touched it accidentally. This is typical of subaqueous traces (Peabody, 1956; Silva et al., 2008). Also, as there are no sequences of traces forming complete traceways, only sequence of feet, the long and laterally compressed tail can be interpreted as the main propelling element in swimming, with the feet working as secondary propellants. This is also evidenced by the morphology of the locomotory appendages.

The greater size of hind limb in relation to the body indicates a propulsive function, while the smaller and unspecialized arms could have been of little help in propelling (e.g., Romer, 1956; Silva et al., 2009). The movement of the fore limbs of mesosaurids seems to have been greatly reduced, possibly restricted to a lateroposterior orientation in swimming.

In basal amniotes, the broad ends of the humerus lie in different planes, frequently about a right angle (Romer, 1956), allowing the typical position of forearm and hand in cursorial reptiles. Such torsion on the humerus of mesosaurids is about $55^{\circ}$ (Sedor, 2004), which restricted the fore limbs in anterolateral movements. The extremities of the radius and ulna, like other aquatic reptiles, have reducing the motion between epipodials and the humerus to a simple flexion (e.g., Romer, 1956; Silva et al., 2009).

The femur is similar in shape to basal terrestrial reptiles, with an elongate oval articular head, and the bone could rather freely rotate in the acetabulum, unlike the restricted movement of the humerus (e.g., Romer, 1956; Sedor, 2004). The tibia and fibula are well developed, short, and are similar to terrestrial forms but somewhat flatter (Romer, 1956). The feet are large compared to the body and close to basal amniote pattern, and there is no evidence for much movement between the tarsus and its proximal or distal articulation, so the feet could act as a paddle. Such reduced mobility in carpal and tarsal elements is common in aquatic tetrapods (e.g., Romer, 1956), which could prevent a terrestrial locomotion for mesosaurids.

So, the mesosaurid traces represented by parallel curved marks were interpreted as drag marks produced by the feet describing an arc movement (Silva et al., 2009). This is typical of aquatic tetrapods which use autopodia as propellants (e.g., Peabody, 1956, 1959; McAllister and Kirby, 1998; Avanzini et al., 2005; Minter and Braddy, 2006). Similar traces from a lacertoid animal, which should swim quite like mesosaurids did, were recorded by Silva et al. (2008). 
Traces with divergent marks are related to opening of the fingers in the propelling phase, in which the webbing is inflated to increase the surface area of feet (Silva et al., 2009). The range of trace lengths and the distance between digits are consistent with the range of dimensions of Mesosauridae (e.g., Williston, 1914; Araújo, 1976; Modesto, 1999, 2010). Besides that, the length of the digits and their position in relation to the body (Williston, 1914; Sedor and Ferigolo, 1999) allow the central digits to preferentially touch the bottom (Silva et al., 2009), although digit $\mathrm{V}$ be the longest. This is corroborated by the presence of traces with five digits, in which the three central digits are most strongly printed (Figure 3D). Digit I is short and possibly touched the bottom only occasionally, leaving small marks in a few traces (Figure 3D).

Long isolated or double marks were attributed to drag marks of fingers, produced when propulsion ceased but the animal continued to move by inertia (Figures 3E,F), originating straight marks, or when propulsion was provided only by undulatory movement of tail, which produces sinuous marks (Silva et al., 2009). Bifurcated marks are probably variants of Z-traces sensu McAllister and Kirby (1998), representing brief interruptions in movement and changes of direction (Figures 3G-I).

Swimming tetrapods can use either continuous undulatory propulsion from the body and tail or discontinuous oscillatory propulsion from the limbs (McAllister, 1989). Animals such sea snakes (e.g., Hydrophiinae, Serpentes) and fishes (e.g., Actinopterygii) show undulatory propulsion provided by the symmetrical and lateral movement of the tail, creating a lateroposterior stroke (McAllister, 1989; Hildebrand, 1995). This kind of propulsion favors speed over maneuverability for the animal. Limbed tetrapods such as turtles, frogs, birds and some mammals can also swim through oscillatory swimming with the limbs acting as paddles, favoring maneuverability over speed (e.g., Hildebrand, 1995). In aquatic squamate, salamanders and crocodilians, arms and legs remain aligned with the body in undulatory swimming, reducing drag. In oscillatory swimming, the limbs are used for a better maneuverability. The mesosaurids were probably able to do both types of swimming (Silva et al., 2009). As the mesosaurids evolved from terrestrial ancestors with a sprawling gait, as well as due to limitations in movements of the

\section{REFERENCES}

Anderson, A. (1976). Fish trail from the early permian of South Africa. Palaeontology 19, 397-409.

Araújo, D. C. (1976). Taxonomia e relações dos proganosauria da bacia do paraná. Anais da Academia Brasileira de Ciências 48, 91-16.

Avanzini, M., García-Ramos, J. C., Lires, J., Menegon, M., Pi-uela, L., and Fernández, L. A. (2005). Turtle tracks from the Late Jurassic of Asturias, Spain. Acta Palaeontol. Pol. 50, 743-755.

Brand, L. R., and Kramer, J. (1996). Underprints of vertebrate and invertebrate trackways in the Permian Coconino sandstone in Arizona. Ichnos 4, 225-230. doi: 10.1080/10420949609380129

Campos, H. B. N., and Silva, R. C. (2010). Traces of a large crocodylian from the Lower Cretaceous Sousa Formation, Brazil. Bull. New Mex. Mus. Nat. Hist. Sci. 51, 109-114.

Canoville, A., and Laurin, M. (2010). Evolution of humeral microanatomy and lifestyle in amniotes, and some comments on paleobiological inferences. Biol. J. Linn. Soc. 100, 384-406. doi: 10.1111/j.1095-8312.2010.01431.x arms, the abduction phase in stroke possibly started on a more lateral stance, with the sole turned posteriorly, and should end with feet in mesial position (Silva et al., 2009). This information is consistent with that presented by Villamil et al. (2015), which estimated the swimming speed and the position of appendages in mesosaurids.

According to Villamil et al. (2015), the mesosaurids were slow swimmers, unable to reach high speeds. Although it is not possible to estimate the speed of swimming based on traces, it is possible to discern those two swimming modes, one slower and other relatively faster than the first. Still according to Villamil et al. (2015), "the forelimbs were disposed along the sides of the chest while the hind limbs were situated parallel to the tail, in a horizontal plane or with the plantar surface toward the tail in a streamlined position. It is also possible that the feet may have occasionally contributed some propulsion." This is in agreement with the data revealed by the traces.

So, the mesosaurids could use the tail for main propulsion, achieving faster speeds, and producing longer traces than the typical pattern. The paddle-like feet could also act as important secondary propellants for greater maneuverability and changes in direction, mainly with slower speeds, producing shorter and curved traces. The hands were probably unable to produce prints during swimming, possibly acting as stabilizers.

\section{CONCLUSION}

The mesosaurid traces were designated as Mesosaurichnium natans and attributed to Mesosauridae (Sauropsida, Proganosauria), occurring until now only in the Irati Formation (Cisuralian, Permian) of Paraná Basin, Brazil. The traces were produced during swimming close to the bottom. The long tail was used for undulatory propulsion, achieving faster speeds than the oscillatory propulsion, in which the feet acted as a secondary propellant, providing more maneuverability over speed.

\section{AUTHOR CONTRIBUTIONS}

All authors listed, have made substantial, direct and intellectual contribution to the work, and approved it for publication.

Cope, E. D. (1886). A contribution to the vertebrate paleontology of Brazil. Proc. Am. Philos. Soc. 23, 7-15.

Diedrich, C. (2000). Neue Wirbeltierfährten aus dem Unteren Muschelkalk (Mitteltrias) des Osnabrücker Berglandes and Teutoburger Waldes (NW-Deutschland) und ihre stratigraphische und paläeogeographische Bedeutung im Germanischen Becken. Neues Jahrb. Geol. Paläeontol. 217, 369-395.

Diedrich, C. (2002). Vertebrate track bed stratigraphy at new megatrack sites in the Upper Wellenkalk Member and orbicularis Member (Muschelkalk, Middle Triassic) in carbonate tidal flat environments of the western Germanic Basin. Palaeogeogr. Palaeoclimatol. Palaeoecol. 183, 185-208. doi: 10.1016/S0031-0182(01)00467-9

Falkingham, P. L., Bates, K. T., Margetts, L., and Manning, P. L. (2011). The 'Goldilocks' effect: preservation bias in vertebrate track assemblages. J. R. Soc. Interface. 8, 1142-1154. doi: 10.1098/rsif.2010.0634

Falkingham, P. L., Hage, J., and Baker, M. (2014). Mitigating the Goldilocks effect: the effects of different substrate models on track formation potential. $R$. Soc. Open Sci. 1:140225. doi: 10.1098/rsos.140225 
Figueiredo Filho, P. M. (1972). A faciologia do grupo passa dois no rio grande do sul. Rev. Bras. Geociências. 2, 216-235.

Foster, J. R., and Lockley, M. G. (1997). Probable crocodilian tracks and traces from the Morrison Formation (Upper Jurassic) of eastern Utah. Ichnos 5, 121-129. doi: 10.1080/10420949709386411

Goldring, R., and Seilacher, A. (1971). Limulid Undertracks and Their Sedimentological Implications. Neues Jahrb. Geol. Palaontol. Abh. 137, 422-442.

Hachiro, J., and Coimbra, A. M. (1991). "Sistemas deposicionais da Formação Irati no Estado de São Paulo,” in SBG, Simpósio de Geologia do Sudeste, Vol. 2, ed S. B. de Geologia (Atas), 405-413.

Hildebrand, M. (1995). Análise da Estrutura dos Vertebrados. Atheneu, São Paulo, 700.

Lavina, E. L. (1991). Geologia sedimentar e paleogeografia do Neopermiano e Eotriássico (Intervalo Kazaniano - Scythiano) da Bacia do Paraná. PhD Thesis, Pós-Graduação em Geociências, Universidade Federal do Rio Grande do Sul.

Lavina, E. L., Araújo-Barberena, D. C., and Azevedo, S. K. (1991). Tempestades de inverno e altas taxas de mortalidade de répteis mesossauros; um exemplo a partir do afloramento passo São Borja, RS. Pesquisas 18, 64-70.

Lockley, M. G. (1991). Tracking Dinosaurs. Cambridge: University Press, 238.

Loope, D. B. (2006). Dry-season tracks in dinosaur-triggered grainflows. Palaios 21, 132-142. doi: 10.2110/palo.2005.p05-55

Lucas, S. G., and Spielmann, J. A. (2009). Tetrapod footprints from the Lower Permian Abo Formation near Bingham, Socorro County, New Mexico. New Mex. Geol. Soc. Guidebook. 60, 299-304.

McAllister, J. A. (1989). "Dakota Formation tracks from Kansas: implications for the recognition of tetrapod subaqueous traces," in Dinosaur Tracks and Traces, eds D. D. Gillete and M. G. Lockley (Cambridge University Press), 343-348.

McAllister, J. A., and Kirby, J. (1998). An occurrence of reptile subaqueous traces in the Moenkopi Formation (Triassic) of Capitol Reef National Park, South Central Utah, USA. Technical Report 98/1, National Park Service. 45-49.

McGregor, J. H. (1908). "Mesosaurus brasiliensis nov. sp," in Relatório Final Comissão de Estudos Minas de Carvão de Pedra do Brasil, Vol. 2, ed I. Nacional (Rio de Janeiro), 301-336.

Mendes, J. C. (1967). “The Passa Dois Group (the Brazilian portion of the Paraná Basin)," in Problems in Brazilian Gondwana Geology, International Symposium on the Gondwana Stratigraphy and Palaeontology, eds J. J. Bigarella, R. D. Becker and I. D. Pinto (Curitiba: Instituto de Geologia), 119-166.

Mikuláš, R. (2010). "Characichnos isp., probable crocodyle swim traces from the miocene of the eské bud? jovice basin, Czech Republic," in Crocodyle Tracks and Traces, Vol. 51, eds J. Milàn, S. G. Lucas, M. G. Lockley, and J. A. Spielmann (Albuquerque: New Mexico Museum of Natural History and Science), 179-182.

Milani, E. J., França, A. B., and Schneider, R. L. (1994). Bacia do Paraná. Bol. Geociências Petrobrás 8, 69-82.

Milani, E. J., Melo, J. H. G., Souza, P. A., Fernandes, L. A., and França, A. B. (2007). Bacia do Paraná. Bol. Geociências Petrobras 15, 265-287.

Milàn, J., and Bromley, R. G. (2006). True tracks, undertracks and eroded tracks, experimental work with tetrapod tracks in laboratory and field. Palaeogeogr. Palaeoclimatol. Palaeoecol. 231, 253-264. doi: 10.1016/j.palaeo.2004. 12.022

Minter, N. J., and Braddy, S. J. (2006). The fish and amphibian swimming traces Undichna and Lunichnium, with examples from the Lower Permian of New Mexico, USA. Palaeontology 49, 1123-1142. doi: 10.1111/j.1475-4983.2006.00588.x

Modesto, S. P. (1999). Observations on the structure of the Early Permian reptile Stereosternum tumidum Cope. Palaeontol. Afr. 35, 7-19.

Modesto, S. P. (2010). The postcranial skeleton of the aquatic parareptile Mesosaurus tenuidens from the Gondwanan Permian. J. Vertebrate Paleontol. 30, 1378-1395. doi: 10.1080/02724634.2010.501443

Oelofsen, B. W., and Araújo, D. C. (1983). Palaecological implications of the distribution of mesosaurid reptiles in the Permian Irati Sea (Paraná Basin), South America. Rev. Bras. Geociências13, 1-6.

Oelofsen, B. W., and Araújo, D. C. (1987). Mesosaurus tenuidens and Stereosternum tumidum from the Permian Gondwana of both Southern Africa and South America. S. Afr. J. Sci. 83, 370-372.

Peabody, F. E. (1956). Ichnites from the Triassic Moenkopi Formation of Arizona and Utah. J. Paleontol. 30, 295-468.
Peabody, F. E. (1959). Trackways of living and fossil Salamanders. Univ. Calif. Publ. Zool. 63, 1-72.

Piñeiro, G., Ramos, A., Goso, C., Scarabino, F., and Laurin, M. (2012). Unusual environmental conditions preserve a Permian mesosaur-bearing Konservat-Lagerstätte from Uruguay. Acta Palaeontol. Pol. 57, 299-318. doi: 10.4202/app.2010.0113

Premaor, E., Fischer, T. V., and Souza, P. A. (2006). Palinologia da Formação Irati (Permiano Inferior da Bacia do Paraná), em Montividiu, Goiás, Brasil. Rev. Museo Argent. Cienc. Nat. 8, 221-230. doi: 10.22179/REVMACN.8.322

Romano, M., and Whyte, M. A. (2010). Crocodilian and other non-dinosaurian tracks and trackways from the Ravenscar Group (Middle Jurassic) of the Cleveland Basin, Yorkshire, UK. New Mex. Mus. Nat. Hist. Sci. Bull. 51, 69-81.

Romer, A. S. (1956). Osteology of the Reptiles. Chicago: Chicago University Press, 772.

Rösler, O., and Tatizana, C. (1983). “As membranas natatórias em Stereosternum tumidum," in Coletânea de trabalhos paleontológicos, DNPM, Série Geológica, Vol. 27, Série Paleontologia e Estratigrafia, ed S. B. de Geologia (Rio de Janeiro: DNPM), 129-131.

Rubidge, B. S. (2005). Reuniting lost continents-fossil reptiles from the ancient Karoo and their wanderlust. South Afr. J. Geol. 108, 135-172. doi: 10.2113/108.1.135

Santos, R. V., Souza, P. A., Alvarenga, C. J. S., Dantas, E. L., Pimentel, M. M., Oliveira, C. G., et al. (2006). Shrimp U-Pb zircon dating and palynology of bentonitic layers from the Permian Irati Formation, Paraná Basin, Brazil. Gondwana Res. 9, 456-463. doi: 10.1016/j.gr.2005.12.001

Santos Neto, E. V. (1993). Caracterização Geoquímica e Paleoambiente Deposicional da Seqüência Carbonato-Pelítica Superior do Membro Assistência, Formação Irati no Estado de São Paulo, Bacia do Paraná. MsC Thesis PósGraduação em Geologia da Universidade Federal do Rio de Janeiro, 203.

Schneider, R. L., Mühlmann, H., Tommasi, E., Medeiros, R. A., Daemon, R. F., and Nogueira, A. A. (1974). "Revisão Estratigráfica da Bacia do Paraná, in Congresso Brasileiro de Geologia, Vol. 28, ed S. B. de Geologia (Porto Alegre: Anais), 41-66.

Sedor, F. A. (2004). "Osteologia do úmero e apêndice locomotor pélvico de Brazilosaurus sanpauloensis Shikama and Ozaki, 1966 (Mesosauridae), da Formação Irati, Permiano Superior da Bacia do Paraná," in Congresso Brasileiro de Herpetologia, 1, Resumos, CD-ROM. Brasil.

Sedor, F. A., and Ferigolo, J. (1999). "Apêndices locomotores escapulares e pélvicos em Brazilosaurus sanpauloensis Shikama and Ozaki, 1966 (Proganosauria, Mesosauridae), Formação Irati, Permiano da Bacia do Paraná,"in Congresso Brasileiro de Paleontologia, 16, Boletim de Resumos, Brasil,104.

Sedor, F. A., and Silva, R. C. (2004). Primeiro registro de pegadas de Mesosauridae (Amniota, Sauropsida) na Formação Irati (Permiano Superior da Bacia do Paraná) do Estado de Goiás, Brasil. Rev. Bras. Paleontol. 7, 269-274. doi: 10.4072/rbp.2004.2.21

Silva, R. C., Barboni, R., Dutra, T., Godoy, M. M., and Binotto, R. B. (2012b). Footprints of large theropod dinosaurs and implications on the age of Triassic biotas from Southern Brazil. J. South Am. Earth Sci. 39, 16-23. doi: 10.1016/j.jsames.2012.06.017

Silva, R. C., Carvalho, I. S., Fernandes, A. C. S., and Ferigolo, J. (2007). "Preservação e contexto paleoambiental das pegadas de tetrápodes da Formação Santa Maria (Triássico Superior) do Sul do Brasil," in Paleontologia: Cenários da Vida. Editora Interciência, ed E. Interciência (Rio de Janeiro), 525-532.

Silva, R. C., Ferigolo, F., Carvalho, I. S., and Fernandes, A. C. S. (2008) Lacertoid footprints from the Upper Triassic (Santa Maria Formation) of Southern Brazil. Palaeogeogr. Palaeoclimatol. Palaeoecol. 262, 140-156. doi: 10.1016/j.palaeo.2008.02.006

Silva, R. C., Fernandes, A. C. S., and Sedor, F. A. (2003). Ocorrência de icnofósseis de invertebrados na Formação Irati (Permiano Superior da Bacia do Paraná, Brasil). Arq. Mus. Nacional. 61, 261-266.

Silva, R. C., Sedor, F. A., and Fernandes, A. C. S. (2009). Ichnotaxonomy, functional morphology and paleoenvironmental context of Mesosauridae tracks from Permian of Brazil. Rev. Bras. Geociências. 39, 705-716.

Silva, R. C., Sedor, F. A., and Fernandes, A. C. S. (2012a). Fossil footprints from Late Permian of Brazil: an example of hidden biodiversity. J. South Am. Earth Sci. 38, 31-43. doi: 10.1016/j.jsames.2012.05.001

Soares, M. B. (2003). A taphonomic model for the mesosaur assemblage of the Irati Formation, Paraná Basin, Brazil. Acta Geol. Hisp. 1, 349-361. 
Swanson, B. A., and Carlson, K. J. (2002). Walk, wade or swim? Vertebrate traces on an Early Permian Lakeshore. Palaios 17, 123-133. doi: 10.1669/0883-1351(2002)017<0123:WWOSVT>2.0.CO;2

Thomson, T. J., and Droser, M. L. (2015). Swimming reptiles make their mark in the Early Triassic: delayed ecologic recovery increased the preservation potential of vertebrate swim tracks. Geology 42, 215-218. doi: 10.1130/ G36332.1

Thomson, T. J., and Lovelace, D. M. (2014). Swim track morphotypes and new track localities from the Moenkopi and Red Peak formations (Lower-Middle Triassic) with preliminary interpretations of aquatic behaviors. New Mex. Mus. Nat. Hist. Sci. Bull. 62, 103-128.

Thulborn, R., and Wade, M. (1989). "A footprint as the history of movement," in Dinosaur Tracks and Traces, eds D. D. Gillete and M. G. Lockley (Cambridge: Cambridge University Press), 51-56.

Villamil, J., Demarco, P. N., Meneghel, M., Blanco, R. R., Jones, W., Rinderknecht, A., et al. (2015). Optimal swimming speed estimates in the Early Permian mesosaurid Mesosaurus tenuidens (Gervais 1865) from Uruguay. Hist. Biol. 28, 963-971. doi: 10.1080/08912963.201s5.1075018

Walker, R. G., and Plint, A. G. (1992). "Wave- and storm-dominated shallow marine systems," in Facies Models-Response to Sea-Level Changes, eds R. G. Walker and N. P. James (St. John's, NL: Geological Association of Canada), 219-238.

Walter, H. (1983). Zur Taxonomie, Ökologie und Biostratigraphie der Ichnia limnisch-terrestrischer Arthropoden des mitteleuropäischen Jungpaläozoikums. Freiberger Forschungschefte 382, 146-193.

Whyte, M. A., and Romano, M. (2001). A dinosaur ichnocoenosis from the Middle Jurassic of Yorkshire, UK. Ichnos 8, 223-234. doi: 10.1080/10420940109380189

Williston, S. W. (1914). Water Reptiles of the Past and Present. Chicago: University of Chicago Press, 251.

Conflict of Interest Statement: The authors declare that the research was conducted in the absence of any commercial or financial relationships that could be construed as a potential conflict of interest.

Copyright (c) 2017 da Silva and Sedor. This is an open-access article distributed under the terms of the Creative Commons Attribution License (CC BY). The use, distribution or reproduction in other forums is permitted, provided the original author(s) or licensor are credited and that the original publication in this journal is cited, in accordance with accepted academic practice. No use, distribution or reproduction is permitted which does not comply with these terms. 